\title{
USING EXECUTIVE INFORMATION SYSTEMS AS A BUSINESS MANAGEMENT TOOL IN LISTED JOHANNESBURG STOCK EXCHANGE (JSE) COMPANIES: AN EXPLORATORY STUDY
}

\author{
Elmarie Papageorgiou: School of Accountancy, University of the Witwatersrand \\ Herman EC de Bruyn: Department of Business Management, University of Johannesburg
}



\section{INTRODUCTION AND BACKGROUND}

The dynamics of an Executive Information System (EIS) resembles the potential of EISs to support management business reconfiguration and explains that by implication the design of information flows to the EIS forming part of the parallel redesign of the management process. This argument explains how the EIS can be helpful to managers and executives to support them in the decision-making process in solving problems, managing their businesses on a daily basis, and operating in a global, digital and competitive environment. The executive's role is expressed by Saunders (1988:119) in stating that: "Information Systems is in fact the heart of the organisation, and if it does not provide you with the management information that you need to effectively manage your organisation, you are going to have serious problems." Findings from the study of Sutherland (1994:7) conclude, "...that active and on-going support is critical to the realisation of EIS benefits." Arnott, Jirachiefpattana and O'Donnell (2007:2078) added that "EIS support the work of senior management by providing rapid access to critical information." Findings by Venter (2002:209), with regard to the investigation of current online reporting of South African practices, conclude that "South African companies are keeping abreast of international trends regarding the use of the Internet as a medium of communication with investors and shareholders." However, the findings do not mention that financial or non-financial information, like an EIS, can be viewed on an online basis to display the most current information. In the study of Averweg and Roldán (2006:625) they argue that 'EIS is a computer-based technology designed in response to the specific need of executives and for making both strategic and tactical decisions." Sawy (1989:57) states that "...practitioners and academics spent the last ten years bringing out the characteristics that distinguish the varieties of information systems, which often resulted in a hair-splitting exercise." Therefore some references used in this exploratory study are older than ten years as these consulted references include all available references to investigate the study to its full extent to incorporate the history and literature of EISs to compare with the thoughts of older studies to the digital era that are still valid and trustworthy. 


\section{PURPOSE OF THE STUDY}

The overall objective of the research is to explore the use of EISs as a business management tool in listed JSE companies and requires an investigation into the use of an EIS as a means to enhance sustainability and strategic competitiveness, improve decision-making as well as address the unmet needs of the different interest groups. In addition, it necessitates the investigation of EIS's relationship with other information systems, minimise problems and solve problems effectively and efficiently.

\section{RESEARCH QUESTIONS}

The first research question to be addressed relates to establishing the existence of EISs in listed JSE companies. The second question identifies the unmet needs of users of EISs. The third and final research question determines whether EISs can be used as a business management tool to evaluate and manage companies, make decisions and solve problems.

\section{LITERATURE STUDY}

A literature study establishes the definition, shortcomings and purposes of EISs, and investigates EISs relationship with other information systems.

\section{Defining an EIS}

The definition of an EIS is divided into two parts: the general and the specific. The three specific components, which are 'executive', 'information' and 'system', form the general component, Executive Information System.

Executives take responsibility for the overall strategic direction of the business and are involved in setting goals, developing policies and strategies for the entire business. Top management must be able "to grasp the importance of information in the company's ability to achieve its strategic objectives" (Stephenson, 1986:31) as they spend most of their day interacting with key people and companies outside their own company.

In addition to these 'skills', executives need accurate and relevant information to make decisions and achieve objectives. Moscove, Simkin and Bagranoff (1990:5) refer to information as meaningful facts or figures that can be used in making decisions. Data on the other hand refers to raw facts or figures with little or no meaning and is not useful to executives for business decision making. Hollander, Denna and Cherrington (2000:7) refer to information as data that is captured, stored, combined, summarised, and organised into information that is meaningful to executives for the decision-making processes. Information needs to be well presented in a standard format in order for executives and management to understand and interpret. Parker (1996:48) argues that "information, when organised and readily accessible, is power." In summary, information is an important business management tool in the decision-making process of executives and top management.

Systems in businesses are manual or automated. New systems have replaced existing systems as new technology has entered businesses in the new digital era. Bocij, Chaffey, Greasley and Hickie (2003:37) define a system as "a collection of interrelated components that work together towards a collective goal." Lessing and Scheepers (2004:34) define a system as a "group of interacting components, working together towards a common goal by accepting inputs, and in a structured conversion process, producing required outputs." Nieman and Bennett (2002:10) state that a business is linked externally to other roleplayers by a series of inputs, internal processes and eventually outputs.

Based on the preceding sections, an EIS can be defined as an integrated framework with references to 'executive', 'information' and 'system'. Since the 1980's several researchers have pointed out the need for EISs and that has filtered into our businesses. Twenty different studies have been investigated defining EISs. The definitions were documented and compared in the original research but for the purpose of this study, Khan's (1996:16) definition was adapted and used:

An EIS transforms data from internal and external sources into quality information which is timely and relevant and add to the strategic value of the business. Furthermore the information includes critical success factors, key performance indicators, stakeholder needs and other important business variables. It reflects the current status and projected trends needed by executives to monitor and control operations, to formulate policy and for decision-making. The EIS analyses, presents and communicates the information through a system that is easy to use, provides access to the information, and can be personalised to the individual needs of the executive. 


\section{Shortcomings of ElSs}

The shortcomings of EISs or the unmet needs of users are not a trouble-free endeavour. The shortcomings of EISs are investigated and discussed from fourteen different studies (Boynton \& Zmud, 1990:291, Byrd \& Marshall, 1996:449, Frolick \& Robichuax, 1995:158, Galliers \& Leidner, 2004:503, Koh \& Watson, 1998:303, Olson \& Courtney, 1992:230, Palvia, Kumar, Kumar \& Hendon, 1996:169, Rockart \& Treacy, 1982:84, Salmeron, 2002:37, Valusek \& Fryback, 1990:141, Walstom \& Wilson, 1997:81, Watson, Watson, Singh \& Homes, 1995:181, Young \& Watson, 1995:154, Xu \& Kaye, 2002:81) and are summarised as follow:

- $\quad$ Getting accurate data, and the difficulties of accessing data needed for EISs.

- Keeping abreast of executives' ever-changing information requirements. This continuing and on-going problem was ranked highest by all the firms investigated.

- $\quad$ Defining the objectives for the EIS. This varied from executive to executive as it was directly related to the management style of the business.

- $\quad$ Another data-related problem that was related to problem one was the combining of data from multiple sources.

- Having sufficient staff and computer resources. But this problem moved down the rankings in later studies as information technology improved to provide businesses with more sophisticated hardware and software and more computer literate staff.

- $\quad$ EISs are not timely enough to provide the most recent and updated information for executives.

- $\quad$ EISs are personalised systems and are customised for use for executives only.

- Close communication with executives is vital for developing systems and therefore executives need to spend time with developers in order to develop EISs.

- $\quad$ EIS user support tends to focus more on the technical support rather than the information support

Factors affecting the efficiency of EISs were identified in a questionnaire addressed by respondents of listed JSE companies. They identified the following as crucial affecting the efficiency of EISs: quality of information, security, availability of information regularly required, improves control and communication, information available on-time in real-time, influences of viruses, the user-friendliness of EISs, increase response time and the increase of productivity among users (Refer to Table 9 for full details). The unmet needs of EIS users and factors affecting the efficiency of EISs are linked to successful EISs that can be used as a business management tool to evaluate and manage companies by the quality of information obtained the highest percentage in both as per Table 7 and 9 . In the interviews, the interviewees were asked to indicate factors that are crucial for EISs to add value. The top four factors are: quality of information, response time, availability of information regularly required and the availability of market indicators.

\section{Purposes of an EIS}

EISs are used in emerging information technology environments to extract information that executives can use to make decisions and solve problems. Twenty-three major purposes of EISs were identified in thirteen studies from the literature as per Table 1, to determine the criteria for their success in listed JSE companies. In addition, purposes were identified and established in the questionnaire as per Table 6 . 


\section{E. Papageorgiou HEC de Bruyn}

Using executive information systems as a business

management tool in listed Johannesburg Stock Exchange

(JSE) companies: an exploratory study

Table 1: Purposes of an EIS

\begin{tabular}{|c|c|c|c|c|c|c|c|c|c|c|c|c|c|c|}
\hline \multirow[t]{2}{*}{ Purposes of EIS } & \multicolumn{14}{|c|}{ Studies } \\
\hline & 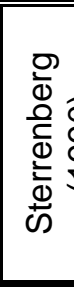 & 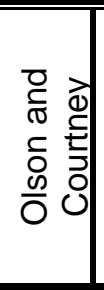 & 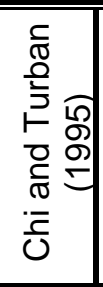 & 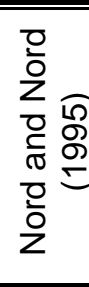 & 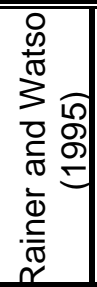 & 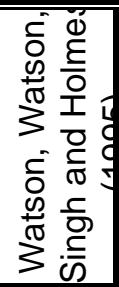 & 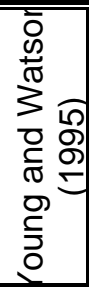 & 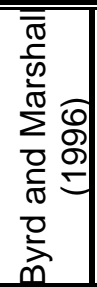 & 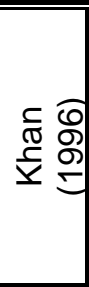 & 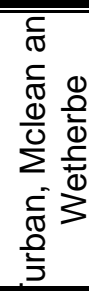 & 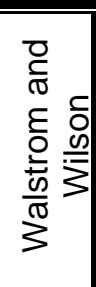 & 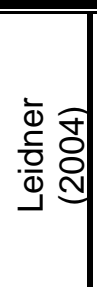 & 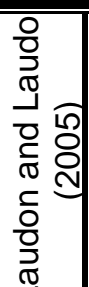 & $\frac{\pi}{0}$ \\
\hline Drill down & $\bar{x}$ & $\bar{x}$ & & $x$ & $x$ & $\bar{x}$ & $\bar{x}$ & $\bar{x}$ & $x$ & $\bar{x}$ & $\bar{x}$ & $x$ & $x$ & \\
\hline Easy access & $\mathrm{x}$ & $x$ & & $\mathrm{x}$ & & & $x$ & $\mathrm{X}$ & $x$ & & & & $x$ & \\
\hline $\begin{array}{l}\text { Status access } \\
\text { mode }\end{array}$ & $x$ & & & & $x$ & & & $\mathrm{X}$ & $\mathrm{x}$ & $x$ & & $x$ & & \\
\hline Exception reporting & $x$ & & & & $\mathrm{x}$ & & & & $\mathrm{x}$ & $x$ & & $\mathrm{x}$ & & \\
\hline $\begin{array}{l}\text { External databases } \\
\text { access }\end{array}$ & & & & & $\mathrm{x}$ & $\mathrm{x}$ & $\mathrm{x}$ & $\mathrm{X}$ & & & & $x$ & & \\
\hline Trend analysis & $x$ & & & & & & & & $\mathrm{x}$ & $\mathrm{x}$ & & $\mathrm{x}$ & & \\
\hline Ad hoc facilities & $x$ & & & & & & & & $\mathrm{x}$ & $\mathrm{x}$ & $x$ & & & \\
\hline $\begin{array}{l}\text { Text, graphs, tables } \\
\text { on one screen }\end{array}$ & $x$ & & & & & & $x$ & $\mathrm{X}$ & $x$ & & & & & \\
\hline $\begin{array}{l}\text { Internal database } \\
\text { access }\end{array}$ & & & & & & $x$ & $x$ & $\mathrm{X}$ & & & & & & \\
\hline Extensive graphics & & & & $\mathrm{x}$ & & & $\mathrm{x}$ & & & & & $\mathrm{x}$ & & \\
\hline Electronic mail & $x$ & $\mathrm{x}$ & & & & & & & & & $\mathrm{x}$ & & & \\
\hline $\begin{array}{l}\text { Internal \& external } \\
\text { information on one } \\
\text { screen }\end{array}$ & $x$ & & & & & & & & $\mathrm{x}$ & & & & $x$ & \\
\hline Security \& control & & & & $x$ & & $x$ & & & & & & & & \\
\hline $\begin{array}{l}\text { Improve } \\
\text { management's } \\
\text { performance }\end{array}$ & & & & & & & & & & & $x$ & & $x$ & \\
\hline $\begin{array}{l}\text { Critical success } \\
\text { factors }\end{array}$ & & & $x$ & & & & & & & $\bar{x}$ & & & & \\
\hline $\begin{array}{l}\text { Multidimensional } \\
\text { analysis }\end{array}$ & & & & & & & & & $x$ & & & & & \\
\hline $\begin{array}{l}\text { Quick \& immediate } \\
\text { access }\end{array}$ & & & & & & & & & & & & & $\bar{x}$ & \\
\hline $\begin{array}{l}\text { Non-keyboard } \\
\text { interface }\end{array}$ & & & & & & & & & & & & $\bar{x}$ & & \\
\hline \begin{tabular}{|l} 
Directly used by \\
executives
\end{tabular} & & & & & & & & $\mathrm{x}$ & & & & & & \\
\hline Colour screens & & & & & & $\mathrm{x}$ & & & & & & & & \\
\hline $\begin{array}{l}\text { Forecasting } \\
\text { capabilities }\end{array}$ & & & $x$ & & & & & & & & & & & \\
\hline $\begin{array}{l}\text { Open-ended } \\
\text { problems } \\
\text { explanations }\end{array}$ & & & $\mathrm{x}$ & & & & & & & & & & & \\
\hline $\begin{array}{l}\text { Standard definitions } \\
\text { across businesses }\end{array}$ & & & & & $x$ & & & & & & & & & \\
\hline
\end{tabular}

Relationship between an EIS and other related information systems 


\section{E. Papageorgiou HEC de Bruyn}

Using executive information systems as a business management tool in listed Johannesburg Stock Exchange (JSE) companies: an exploratory study

Although an EIS is an extremely important information system within businesses, it is not the one and only formal framework that provides information within businesses. Formal and informal information systems integrate or merge with each other to provide information and from that information the level of decision-making is determined. Table 2 shows the relationship between an EIS and other related information systems.

Table 2: Relationship between an EIS and other information systems

\begin{tabular}{|c|c|c|c|}
\hline $\begin{array}{l}\text { Information } \\
\text { System }\end{array}$ & Involvement & Deliverables & Main features \\
\hline EIS & $\begin{array}{l}\text { Top management, } \\
\text { executives, senior } \\
\text { managers }\end{array}$ & $\begin{array}{l}\text { Internal and external } \\
\text { information that } \\
\text { affects or may affect } \\
\text { the business }\end{array}$ & $\begin{array}{l}\text { Analyse, compare and highlight trends to help } \\
\text { in decision-making }\end{array}$ \\
\hline AIS & $\begin{array}{l}\text { Staff that are } \\
\text { responsible for the daily } \\
\text { capturing of } \\
\text { transactions. Linked to } \\
\text { EIS for drill-down } \\
\text { facilities. }\end{array}$ & $\begin{array}{l}\text { Standard reports, } \\
\text { graphics and other } \\
\text { ad hoc reports }\end{array}$ & $\begin{array}{l}\text { Provides functions for numerous financial } \\
\text { activities and transactions that take place in } \\
\text { the business }\end{array}$ \\
\hline CBIS & $\begin{array}{l}\text { All users of information } \\
\text { systems }\end{array}$ & $\begin{array}{l}\text { Increase computer } \\
\text { literacy }\end{array}$ & $\begin{array}{l}\text { Growth in cheaper, friendlier and better } \\
\text { technology }\end{array}$ \\
\hline DIEIS & Executives & $\begin{array}{l}\text { An EIS which } \\
\text { incorporates a } \\
\text { distributed artificial } \\
\text { intelligence into the } \\
\text { information process }\end{array}$ & Is a multiple problem solving mechanism \\
\hline DSS & $\begin{array}{l}\text { Analysts, managers and } \\
\text { other professionals }\end{array}$ & $\begin{array}{l}\text { Forecasting, } \\
\text { resource allocation } \\
\text { models, ad hoc } \\
\text { queries }\end{array}$ & $\begin{array}{l}\text { Provides computerised support to complex } \\
\text { non-routine and partially structures decisions }\end{array}$ \\
\hline ES & $\begin{array}{l}\text { Experts and specialist } \\
\text { and non specialist that } \\
\text { can make decisions }\end{array}$ & Special reports & $\begin{array}{l}\text { Uses knowledge to diagnose problems, } \\
\text { propose solutions to those problems or train } \\
\text { employees }\end{array}$ \\
\hline ESS & Executives & $\begin{array}{l}\text { Internal transaction } \\
\text { data and external } \\
\text { data }\end{array}$ & $\begin{array}{l}\text { An EIS that includes capabilities of data } \\
\text { analysis. Offers single information processing } \\
\text { mechanism. Routine use of computer-based } \\
\text { system. }\end{array}$ \\
\hline KMS & $\begin{array}{l}\text { Knowledge workers: } \\
\text { Personnel who } \\
\text { specialise in strategic } \\
\text { information for } \\
\text { executives }\end{array}$ & Ad hoc reports & $\begin{array}{l}\text { Creates, codifies and distributes information } \\
\text { about the business and issues that are } \\
\text { significance to the business }\end{array}$ \\
\hline MIS & $\begin{array}{l}\text { Middle management in } \\
\text { functional areas }\end{array}$ & $\begin{array}{l}\text { Periodic, standard } \\
\text { ad hoc reports }\end{array}$ & $\begin{array}{l}\text { Organises, summarises and displays } \\
\text { decision-relevant information in functional } \\
\text { areas }\end{array}$ \\
\hline MSS & Managers & $\begin{array}{l}\text { Processed data, } \\
\text { external data, non- } \\
\text { financial data and } \\
\text { drill-down facility }\end{array}$ & $\begin{array}{l}\text { Can be use in a structured environment that } \\
\text { supports managers in their day-to-day tasks } \\
\text { and decision-making }\end{array}$ \\
\hline OLAP & $\begin{array}{l}\text { For users to formulate } \\
\text { own queries in real time }\end{array}$ & $\begin{array}{l}\text { Formulate own } \\
\text { queries, to standard } \\
\text { reports }\end{array}$ & $\begin{array}{l}\text { Analyses and consolidates large } \\
\text { multidimensional information stored in data } \\
\text { warehouse }\end{array}$ \\
\hline$\overline{S I S}$ & Top management & EIS, MIS and DSS & $\begin{array}{l}\text { Supports and shapes the competitive strategy } \\
\text { of the business in the long term }\end{array}$ \\
\hline
\end{tabular}

Source: Adapted from Turban (1993:23) and Galliers and Leidner (2004:508). 


\section{RESEARCH METHODOLOGY}

The research study used a mixed method design that is quantitative and qualitative in nature. Questionnaires were distributed via e-mail to 334 listed JSE companies for the attention of executives and top management. A sample of companies was selected randomly from the returned questionnaires, to conduct interviews. The interviews consist of a new set of structured questions (a different set of questions for each group; companies with EISs, companies with no EISs and companies plan in implement EISs) explaining clearly what information was needed and a copy of the cover letter for the interview was e-mailed to eleven interviewees stating the date, time and purpose of the interview. The raw data was electronically collected from the questionnaires by the server and thereafter analysed. The stratification of the different interview groups and the numbers of companies to be interviewed were as follows:

1. Group 1: Companies with EISs - 5 Companies

2. Group 2: Companies with no EISs - 4 Companies

3. Group 3: Companies planning to implement EISs - 2 Companies

The data collected from the interviews were documented and analysed; in addition the background and general observations from the interviews of all the companies per group were analysed and explained. For the questionnaires the statistical analysis was done by the Statistical Consultation Services at the institution. The software package that was used in the analysis was the Statistical Package for the Social Sciences (SPSS) 15.0 Family. A statistical analysis was conducted as basic frequencies were used in frequency tables to present the information. Cross tabulations with appropriate tests for independence were conducted to determine whether two categorical variables were related. Descriptive analysis provided a very useful initial examination of the data and was the initial phase in the statistical analysis. The Pearson chi-square test was used to determine the relationship between categories in frequency tables (Diamantopoulos and Schlegelmilch, 1997:203). For the interviews the data was collected and gathered by the interview process, documented and analysed qualitatively as a content analysis was used to determine the relationships between the data gathered.

\section{FINDINGS}

Each of these two stages made a contribution to the study.

\section{Quantitative Results - Questionnaires}

The survey data from the questionnaires provided useful insight into JSE listed companies who have already implemented EISs and for those who are interested in implementing EISs. The data confirmed that there is a growing interest in EISs. Of the sixty five companies that responded, (a response rate of $19.5 \%) 38.5 \%$ companies have currently implemented EISs and $20 \%$ of companies plan to implement EISs. Companies have responded as followed:

- $\quad$ Group 1 - Twenty five companies with EISs

- $\quad$ Group 2 - Twenty seven companies with no EISs; and

- $\quad$ Group 3 - Thirteen companies plan to implement EISs

Table 3 shows that rank order of the respondent's position in the company. Although questionnaires were addressed to top management it is interesting to note that other levels participated substantially; of interest is the fact that the response rate of managers was as high as $17.0 \%$. 
E. Papageorgiou HEC de Bruyn
Using executive information systems as a business management tool in listed Johannesburg Stock Exchange (JSE) companies: an exploratory study

Table 3: Respondents by position in the company

\begin{tabular}{|l|l|l|}
\hline \hline Respondents by position in the company & Frequency & Valid Percent \\
\hline \hline CEO & 19 & $29.3 \%$ \\
\hline FD & 16 & $24.7 \%$ \\
\hline Manager & 11 & $17.0 \%$ \\
\hline Director & 8 & $12.4 \%$ \\
\hline MD & 2 & $3.1 \%$ \\
\hline OTHER & & \\
\hline CFO & 2 & $3.0 \%$ \\
\hline Company secretary/executive & 2 & $3.0 \%$ \\
\hline CIO & 1 & $1.5 \%$ \\
\hline Company Secretary & 1 & $1.5 \%$ \\
\hline General Manager: Group Finance & 1 & $1.5 \%$ \\
\hline $\begin{array}{l}\text { Group Executive: } \\
\text { Communications }\end{array}$ & 1 & $1.5 \%$ \\
\hline Non-executive director & 1 & $1.5 \%$ \\
\hline Total Corporate & 65 & $100.0 \%$ \\
\hline \hline
\end{tabular}

Table 4 represents a rank ordered listing of the elements available on the companies' Web site. These fields were compulsory and required inputs from all addressees. The percentages of respondents reporting to the availability of annual financial elements on the company's Web site indicate that displaying current information focus heavily on the full annual report (92.3\%), followed by the chairman's report $(52.3 \%)$ and then corporate information (47.7\%). The four least elements available on the company's Web site were both audit report and links to non-financial information (38.5\%), then lastly both elements at $35.4 \%$, changes in equity statement and year-end-review.

Table 4: Annual financial elements available on the company's web site

\begin{tabular}{|l|l|l|}
\hline $\begin{array}{l}\text { Annual financial elements available on the company's } \\
\text { Web site }\end{array}$ & Marked & \\
\hline \hline & Count & Percentage \\
\hline Full Annual Report & 60 & $92.3 \%$ \\
\hline Chairman's Report & 34 & $52.3 \%$ \\
\hline Corporate Information & 31 & $47.7 \%$ \\
\hline Financial Summary & 30 & $46.3 \%$ \\
\hline Balance Sheet & 29 & $44.6 \%$ \\
\hline Income Statement & 29 & $44.6 \%$ \\
\hline Cash Flow Statement & 27 & $41.5 \%$ \\
\hline Notes to the accounts & 26 & $40.0 \%$ \\
\hline Management Report & 26 & $40.0 \%$ \\
\hline Audit Report & 25 & $38.5 \%$ \\
\hline
\end{tabular}


E. Papageorgiou HEC de Bruyn
Using executive information systems as a business management tool in listed Johannesburg Stock Exchange (JSE) companies: an exploratory study

\begin{tabular}{|l|l|l|}
\hline Links to non-financial information & 25 & $38.5 \%$ \\
\hline Changes in Equity Statement & 23 & $35.4 \%$ \\
\hline Year-end-Review & 23 & $35.4 \%$ \\
\hline Other & 7 & $10.8 \%$ \\
\hline
\end{tabular}

Potentially an EIS fulfil a wide range of purposes but as per Table 5 only the main purposes were listed. This question was not compulsory and respondents could select more than one purpose for using EISs. Nearly thirty seven percent (36.9\%) use EIS as a decision-making tool and twenty three $(23.1 \%)$ use EIS as a problem solving tool. Only $9.2 \%$ percent of respondents use electronic mail as one of the purposes of EISs. This figure seems low but until recently keyboards were the only input device to capture information as executives have poor typing skills as they relate better to graphs to understand the current results and therefore can detect trends quickly. Textual information provides the interpretation of data and reasons for variations on current and budget figures. Tables provide greater detail than graphs as a data table can be inserted at the bottom of the graph for further explanation of data. Tables also support variance analyses. Some companies use EISs as a data sheet to store the data of their customers and suppliers information and therefore can be easily accessible when needed.

Table 5: Purpose/s for using EISs

\begin{tabular}{|l|l|l|}
\hline Purpose/s for using EISs & Marked & \\
\hline \hline & Count & Percentage \\
\hline Decision-making & 24 & $36.9 \%$ \\
\hline Problem solving & 15 & $23.1 \%$ \\
\hline Quick reference & 8 & $12.3 \%$ \\
\hline Scheduling & 6 & $9.2 \%$ \\
\hline Electronic mail & 6 & $9.2 \%$ \\
\hline Other & 3 & $4.6 \%$ \\
\hline \hline
\end{tabular}

The respondents could select more than one person as main users of EISs as per Table 6. This question was not compulsory and explores the level of management that is utilising EISs within the business. This mixing of personnel creates an environment of different skills. Although EISs are intended for more senior managers it is interesting to note all levels participate substantially.

Table 6: Main users of EISs

\begin{tabular}{|l|l|l|}
\hline \hline Main users of EISs & Marked \\
\hline \hline & Count & Percentage \\
\hline Executive & 22 & $33.8 \%$ \\
\hline CEO & 17 & $26.2 \%$ \\
\hline Accountant & 15 & $23.1 \%$ \\
\hline Manager & 13 & $20.0 \%$ \\
\hline MIS & 10 & $15.4 \%$ \\
\hline Other & 3 & $4.6 \%$ \\
\hline \hline
\end{tabular}




\section{E. Papageorgiou HEC de Bruyn}

Using executive information systems as a business management tool in listed Johannesburg Stock Exchange (JSE) companies: an exploratory study

There was definitely a significant relationship evident between decision-making and problem solving as per Table 5 versus quality and integrity of information as per Table 7.

Table 7: Criteria for the success of EISs

\begin{tabular}{|l|l|l|}
\hline \hline Criteria for the success of EISs & Marked & \\
\hline \hline & Count & Percentage \\
\hline Quality of information & 23 & $35.4 \%$ \\
\hline Integrity of information & 21 & $32.3 \%$ \\
\hline User-friendly & 16 & $24.6 \%$ \\
\hline Quick response time & 15 & $23.1 \%$ \\
\hline Decision-making & 13 & $20.0 \%$ \\
\hline Regularly updated & 13 & $20.0 \%$ \\
\hline Management involvement & 12 & $18.5 \%$ \\
\hline Better communication among management & 10 & $15.4 \%$ \\
\hline Cost & 9 & $13.8 \%$ \\
\hline Interest of staff & 0 & $0.0 \%$ \\
\hline Other & 1 & $1.5 \%$ \\
\hline \hline
\end{tabular}

The respondents selected financial information available on their EISs as per Table 8. This question was compulsory. Table 8 presents a rank ordered listing per Yes, regular upgraded. The highest four types of financial information that are upgraded on a regular basis are both Income statement and comparative figures (88.0\%), followed by both Balance sheet and Cash flow statement $(84.0 \%)$. The lowest three types of financial information that are not upgraded are investors guide $(68.0 \%)$, followed by Value Added Tax (VAT) reports $(76.0 \%)$ and lastly taxation enquires (80.0\%).

Table 8: Financial information available on EISs

\begin{tabular}{|c|c|c|c|c|c|c|}
\hline \multirow[t]{2}{*}{ Financial information available on EISs } & \multicolumn{2}{|c|}{$\begin{array}{l}\text { Yes, regularly } \\
\text { upgraded }\end{array}$} & \multicolumn{2}{|c|}{$\begin{array}{l}\text { Yes, but not } \\
\text { always } \\
\text { upgraded }\end{array}$} & \multicolumn{2}{|l|}{ No } \\
\hline & Count & $\%$ & Count & $\%$ & Count & $\%$ \\
\hline Income Statement & 22 & $88.0 \%$ & 1 & $4.0 \%$ & 2 & $8.0 \%$ \\
\hline Comparative Figures & 22 & $88.0 \%$ & 1 & $4.0 \%$ & 2 & $8.0 \%$ \\
\hline Balance Sheet & 21 & $84.0 \%$ & 1 & $4.0 \%$ & 3 & $12.0 \%$ \\
\hline Cash flow Statement & 21 & $84.0 \%$ & 1 & $4.0 \%$ & 3 & $12.0 \%$ \\
\hline $\begin{array}{l}\text { Actual versus Budget figures for the } \\
\text { company }\end{array}$ & 20 & $80.0 \%$ & 0 & $0.0 \%$ & 5 & $20.0 \%$ \\
\hline Financial Ratios & 18 & $72.0 \%$ & 2 & $8.0 \%$ & 5 & $20.0 \%$ \\
\hline Financial Summary & 18 & $72.0 \%$ & 4 & $16.0 \%$ & 3 & $12.0 \%$ \\
\hline Management Report & 17 & $68.0 \%$ & 3 & $12.0 \%$ & 5 & $20.0 \%$ \\
\hline $\begin{array}{l}\text { Graphs on Financial Ratios / Budget vs. } \\
\text { Actual }\end{array}$ & 16 & $64.0 \%$ & 2 & $8.0 \%$ & 7 & $28.0 \%$ \\
\hline
\end{tabular}


E. Papageorgiou HEC de Bruyn
Using executive information systems as a business management tool in listed Johannesburg Stock Exchange (JSE) companies: an exploratory study

\begin{tabular}{|l|l|l|l|l|l|l|}
\hline Trend Analysis & 16 & $64.0 \%$ & 1 & $4.0 \%$ & 8 & $32.0 \%$ \\
\hline Exchange Rates information & 15 & $60.0 \%$ & 0 & $0.0 \%$ & 10 & $40.0 \%$ \\
\hline Drill down to Chart of Account level & 13 & $52.0 \%$ & 3 & $12.0 \%$ & 9 & $36.0 \%$ \\
\hline 5-Year Review & 12 & $48.0 \%$ & 5 & $20.0 \%$ & 8 & $32.0 \%$ \\
\hline Links to the JSE & 12 & $48.0 \%$ & 3 & $12.0 \%$ & 10 & $40.0 \%$ \\
\hline On-time, real-time & 12 & $48.0 \%$ & 4 & $16.0 \%$ & 9 & $36.0 \%$ \\
\hline Database Access & 11 & $44.0 \%$ & 2 & $8.0 \%$ & 12 & $48.0 \%$ \\
\hline Report Writer for Formal Reports & 10 & $40.0 \%$ & 3 & $12.0 \%$ & 12 & $48.0 \%$ \\
\hline Audit Report & 10 & $40.0 \%$ & 3 & $12.0 \%$ & 12 & $48.0 \%$ \\
\hline Exception Reports & 10 & $40.0 \%$ & 3 & $12.0 \%$ & 12 & $48.0 \%$ \\
\hline Interest Rates & 9 & $36.0 \%$ & 2 & $8.0 \%$ & 14 & $56.0 \%$ \\
\hline Fixed Asset Register & 7 & $28.0 \%$ & 3 & $12.0 \%$ & 15 & $60.0 \%$ \\
\hline Capability to do What-if-analysis & 6 & $24.0 \%$ & 3 & $12.0 \%$ & 16 & $64.0 \%$ \\
\hline Investors Guide & 6 & $24.0 \%$ & 2 & $8.0 \%$ & 17 & $68.0 \%$ \\
\hline VAT Reports & 5 & $20.0 \%$ & 1 & $4.0 \%$ & 19 & $76.0 \%$ \\
\hline Taxation Enquiries & 4 & $16.0 \%$ & 1 & $4.0 \%$ & 20 & $80.0 \%$ \\
\hline Other & 3 & $12.0 \%$ & 2 & $8.0 \%$ & 20 & $80.0 \%$ \\
\hline \hline
\end{tabular}

A four-point scale was used to measure the nineteen factors that affected the efficiency of EISs. A definite relationship between Table 7, 'Criteria for the success of EISs', and Table 9, 'Factors affecting the efficiency of EISs', was noted regarding the quality of information, security (integrity) and the response time.

Table 9: factors affecting the efficiency of EISs

\begin{tabular}{|l|l|l|l|l|l|l|l|l|}
\hline $\begin{array}{l}\text { Factors affecting the } \\
\text { efficiency of EISs }\end{array}$ & \multicolumn{2}{|l|}{ Crucial } & Important & Minor & None \\
\hline \hline & Count & $\%$ & Count & $\%$ & Count & $\%$ & Count & $\%$ \\
\hline Quality of Information & 20 & $80.0 \%$ & 5 & $20.0 \%$ & 0 & $0.0 \%$ & 0 & $0.0 \%$ \\
\hline Security & 17 & $68.0 \%$ & 5 & $20.0 \%$ & 2 & $8.0 \%$ & 1 & $4.0 \%$ \\
\hline $\begin{array}{l}\text { Availability of information } \\
\text { regularly required }\end{array}$ & 15 & $60.0 \%$ & 10 & $40.0 \%$ & 0 & $0.0 \%$ & 0 & $0.0 \%$ \\
\hline Response Time & 14 & $56.0 \%$ & 11 & $44.0 \%$ & 0 & $0.0 \%$ & 0 & $0.0 \%$ \\
\hline $\begin{array}{l}\text { Improves control and } \\
\text { communication }\end{array}$ & 13 & $52.0 \%$ & 10 & $40.0 \%$ & 2 & $8.0 \%$ & 0 & $0.0 \%$ \\
\hline On-time, real-time & 12 & $48.0 \%$ & 6 & $24.0 \%$ & 5 & $20.0 \%$ & 2 & $8.0 \%$ \\
\hline Viruses & 12 & $48.0 \%$ & 7 & $28.0 \%$ & 5 & $20.0 \%$ & 1 & $4.0 \%$ \\
\hline User-friendliness & 12 & $48.0 \%$ & 13 & $52.0 \%$ & 0 & $0.0 \%$ & 0 & $0.0 \%$ \\
\hline $\begin{array}{l}\text { Respond time to competitors } \\
\text { must quicker }\end{array}$ & 11 & $44.0 \%$ & 6 & $24.0 \%$ & 6 & $24.0 \%$ & 2 & $8.0 \%$ \\
\hline Increase Productivity & 9 & $36.0 \%$ & 15 & $60.0 \%$ & 0 & $0.0 \%$ & 1 & $4.0 \%$ \\
\hline
\end{tabular}




\begin{tabular}{|l|l|l|l|l|l|l|l|l|}
\hline Lack of resources & 7 & $28.0 \%$ & 14 & $56.0 \%$ & 3 & $12.0 \%$ & 1 & $4.0 \%$ \\
\hline Identify New Opportunities & 6 & $24.0 \%$ & 12 & $48.0 \%$ & 5 & $20.0 \%$ & 2 & $8.0 \%$ \\
\hline Saving Cost & 5 & $20.0 \%$ & 14 & $56.0 \%$ & 6 & $25.0 \%$ & 0 & $0.0 \%$ \\
\hline $\begin{array}{l}\text { Availability of Market } \\
\text { Indicators }\end{array}$ & 4 & $16.0 \%$ & 10 & $40.0 \%$ & 7 & $28.0 \%$ & 4 & $16.0 \%$ \\
\hline Knowledge of new technology & 4 & $16.0 \%$ & 10 & $40.0 \%$ & 8 & $32.0 \%$ & 3 & $12.0 \%$ \\
\hline Lack of interest & 3 & $12.0 \%$ & 11 & $44.0 \%$ & 8 & $32.0 \%$ & 3 & $12.0 \%$ \\
\hline $\begin{array}{l}\text { Links to JSE, External } \\
\text { Databases }\end{array}$ & 3 & $12.0 \%$ & 6 & $24.0 \%$ & 8 & $32.0 \%$ & 8 & $32.0 \%$ \\
\hline Software Upgrades & 2 & $8.0 \%$ & 14 & $56.0 \%$ & 6 & $24.0 \%$ & 3 & $12.0 \%$ \\
\hline Other & 2 & $8.0 \%$ & 0 & $0.0 \%$ & 5 & $20.0 \%$ & 18 & $72.0 \%$ \\
\hline \hline
\end{tabular}

The thirteen companies that planned to implement EISs were added to the twenty five companies that already had EISs, totalling $58.5 \%$ of all the companies that participated in the questionnaire. A Pearson Chi-square test for independence was conducted to determine whether the size of a company is related to it having an EIS and companies planning to implement an EIS. The proportion of large companies (more than 2500 employees) that has implemented an EIS (76.9\%) was significantly different from the proportion of both: small (less than 100 employees; 46.7\%) companies and medium (100 to 2500 employees; $45.8 \%)$ companies $\left(x^{2}(2)=6.085, \rho=0.048\right)$. The magnitude of the association was moderate (Cramer's V: 0.306). The practical value of the test determined that larger companies (more than 2500 employees) have the tendency to have an EIS and plan to implement an EIS in relation to smaller companies (less than 100 employees).

Table 10: Association between size of the company and existence of an EIS together with the implementation of an EIS

\begin{tabular}{|c|c|c|c|c|c|c|}
\hline \multirow{3}{*}{$\begin{array}{l}\text { Number of } \\
\text { Employees/ Size of } \\
\text { the Company }\end{array}$} & \multicolumn{4}{|c|}{ Have EIS and planning to implement an EIS } & \multirow{2}{*}{\multicolumn{2}{|c|}{ Total }} \\
\hline & \multicolumn{2}{|c|}{ Yes } & \multicolumn{2}{|c|}{ No } & & \\
\hline & Count & $\begin{array}{l}\text { \% within } \\
\text { Number of } \\
\text { Employees }\end{array}$ & Count & $\begin{array}{l}\text { \% within } \\
\text { Number of } \\
\text { Employees }\end{array}$ & Count & $\begin{array}{l}\% \text { within Number } \\
\text { of Employees }\end{array}$ \\
\hline $\begin{array}{l}\text { Less than } 100 \\
\text { employees }\end{array}$ & 7 & $46.7 \%$ & 8 & $53.3 \%$ & 15 & $100.0 \%$ \\
\hline 100-2500 employees & 11 & $45.8 \%$ & 13 & $54.2 \%$ & 24 & $100.0 \%$ \\
\hline $\begin{array}{l}\text { More than } 2500 \\
\text { employees }\end{array}$ & 20 & $76.9 \%$ & 6 & $23.1 \%$ & 26 & $100.0 \%$ \\
\hline Total & 38 & $58.5 \%$ & 27 & $41.5 \%$ & 65 & $100.0 \%$ \\
\hline
\end{tabular}

Qualitative Results - Interviews

Eleven executives from the respondents of the questionnaire were interviewed to determine how EISs or other information systems were used by executives and management to create sustainable strategic value, and how the systems influenced the decision making process.

Companies with EISs: Results of Group 1: A successful EIS provides the executive with the necessary real-time information that is needed in decision making and solving problems under time pressure. An EIS is a trusted source of information to be used as a business management tool for the companies in Group 1. All the companies have used EISs for five years plus. The number of users accessing EISs varied from twenty six to over five hundred users. The accountant was the most prolific user. The three most ranked motivation factors and features were; to improve the effectiveness and efficiency of executives, to provide 
easier and faster access to information, and finally, to interface with other software. The four problems that occurred the most in all the companies were: combining data from multiple sources, inaccurate data, executives' ever changing information requirements and lower level users enter inaccurate information on EISs as executives suffer the consequences due to these actions. The five top-ranked purposes of EISs were: trend analysis, drill down facility, critical success factors, exception reporting, and finally, quick and immediate access. The following five factors of EISs are the most crucial to add strategic value within companies: quality of information, response time, availability of information regularly required, availability of market indicators, and finally, viruses. Companies identified the following areas to improve EISs: to handle volume of data faster, accessing relevant information, and automated systems.

Companies with no EISs: Results of Group 2: Companies in Group 2 do not have EISs, however two companies intend to implement an EIS. Clearly, the other two companies will not adopt an EIS if there is no value in doing so. However, if the company does not perceive a need for the use and ability of an EIS, it is likely that the EIS will have little perceived value. This was confirmed in the interview where it was stated that there was no benefit in adopting EIS technology as it had no impact on the selling of the product/service of the business. The CEO believed that the current systems were sufficient as the main purpose of the company was to produce goods rather than needing more data. The main reasons for not considering an EIS were: high cost, 'own' information system is sufficient but not as sophisticated as defined, there are other ways of collecting information like meetings, interaction with staff and reports, the company is diversified and an EIS can only work if all the underlying data into the EIS is regularly updated and interfaces are co-ordinated. Companies were asked from where they accessed their information and from which media they preferred to source information. All internal information was accessed from their accounting system and electronic-mail, and external information from printed media forms. All financial information was distributed as a paper-based booklet to the Executive Committee and/or Board of the company as the only source of information. Other powerful methods to extract information were Excel, exception reports, informal EISs, databases and forecasting tools for historical data.

Companies plan to implement EISs: Results of Group 3: One company planned to implement an EIS over a six month period as phase one and the other company had already implemented an EIS in six of its thirteen operations. Both companies felt that the EIS: would improve the immediate availability of information and the drill down to transaction level, provide a system that is user-friendly, decrease the working days substantially to produce consolidated Group results and increase the strategic value for decision making and immediate problem solving. The EIS is supported and empowered by the CEOs, FD and Company Secretary. Both the interviewees seek quicker, better and more efficient ways to do their day-to-day activities and have timeous reports. Both companies have a small staff complement and are management companies that provide a service. Currently both companies' management reports are paper-based. With the implementation of an EIS it will enhance the communication capabilities and improve the existing database of the company. Other powerful tools that are used are Excel with macros, Visual Basic and statistical data programs to extract information for decision-making and solving problems.

\section{MANAGERIAL IMPLICATIONS AND RECOMMENDATIONS}

The research provides guidance for future research as this study was an exploratory study using EISs as a business management tool in listed JSE companies. An area which could be investigated further includes a more comprehensive analysis and follow-up of the sample of the listed JSE companies under review regarding companies planning to implement EISs. Another area which could be developed further is the comparison of listed JSE companies in the same industry with in-depth investigations in all levels of the company. Managerial implications for this study confirmed that using an EIS as a business management tool, added value to their business, enabled executives and top management to access information according to user-defined criteria and to promote information-based insight. The results provide insights to use EISs as a business management tool that contributes to the performance of companies to make decisions and to solve problems much quicker in a competitive environment. As EISs spread and evolve over time, additional users are given access to the system, more information is added and additional structures are put in place.

\section{CONCLUSIONS}

All the listed JSE companies that responded to the questionnaire and/or participated in interviews represent eight of the twelve industries. From the questionnaire it was evident that companies with an EIS or planning to implement an EIS view an EIS as: an excellent business management tool which 


\section{E. Papageorgiou HEC de Bruyn}

Using executive information systems as a business

management tool in listed Johannesburg Stock Exchange

(JSE) companies: an exploratory study

makes use of standard tools and built-in features, critical for real-time decision-making, solving problems and creating a competitive edge. It is clear from the results of the questionnaire that an EIS creates and adds strategic value to companies. The speed of the decision-making process definitely increases the rapidity of problem identification since EISs are used by executives, top management and managers. Companies with an EIS all confirmed that EISs can be of assistance in the decision-making process. The results of the interviews indicated that smaller companies were not adopting EISs. The main reasons for companies not adopting EISs varied and included some of the following reasons: the small size of the company, staff complement consisted of $41 \%$ factory workers or mainly engineers, high cost, underlying systems not compatible, 'own' information system was sufficient but not as sophisticated as defined, other ways of collecting information and/or the company was too diversified. However two companies, who originally reported not to have had an EIS, are currently investigating implementing an EIS. The main reasons that these companies have decided to implement an EIS includes the following: major expansions in the company, to improve the immediate availability of information, drill down facility to transaction level, user-friendliness, to decrease working days substantially to produce consolidated group results, quicker and better ways to improve their daily routine and/or reduce or eliminate paper-based reports. A final reason was to be able to produce a consolidated view of the company and group financial results on a timeous basis to enable feedback to top management. 


\section{REFERENCES}

Arnott, D. Jirachiefpattana, W. and O'Donnell, P. 2007. Executive information systems development in an emerging economy. Decision Support Systems. 42(4):2078-2084.

Averweg, U.R. and Roldán, J.I. 2006. Executive information system implementation in organisations in South Africa and Spain: A comparative analysis. Computer Standards \& Interfaces, 58(6):625-634.

Bocij, P. Chaffey, D. Greasley, A. and Hickie, S. 2003. Business information systems: Technology, development and management for the e-business $\left(2^{\text {nd }} \frac{\text { ed. }}{\text { e. }}\right.$. Harlow:Prentice-Hall.

Boynton, A.C. and Zmud, R.W. 1990. Management information systems. Illinois USA:Harper Collins.

Byrd, T.A. and Marshall, T. 1996. Corporate culture, related chief executive officer traits, and the development of executive information systems. Computers in Human Behaviour, 12(3):449-464.

Chi, R.T. and Turban, E. 1995. Distributed intelligent executive information systems. Decision Support Systems, 14(2):117-130.

Diamantopoulos, A. and Schlegelmilch, B.B. 1997. Taking the fear out of data analysis. London:The Dryden Press.

Frolick, M.N. and Robichaux, B.P. 1995. EIS information requirements determination: Using a group support system to enhance the strategic business objectives method. Decision Support Systems. 14(2):157-170.

Galliers, R.D. and Leidner, D.E.. 2004. Strategic information management: Challenges and strategies in managing information systems. $\left(3^{\text {rd }} \mathrm{ed}\right.$.). Oxford:Elsevier.

Hollander, A.S., Denna, E.I. and Cherrington, J.O. 2000. Accounting, information technology, and business solutions $\left(2^{\text {nd }}\right.$ ed.). Singapore:Irwin.

Khan, S.J. 1996. The benefits and capabilities of executive information systems. Johannesburg:University of the Witwatersrand (MBA).

Koh, C. and Watson, H.J. 1998. Data management in executive information systems. Information \& Management. 33(6):301-312.

Laudon, K.C. and Laudon, J.P. 2005. Essentials of management information systems $\left(6^{\text {th }}\right.$ ed.). New Jersey: Prentice-Hall.

Leidner, D.E. 2004. The information technology - Organizational culture relationship: Understanding information culture: integrating knowledge management system into organizations in Galliers RD \& Leidner DE, Strategic Information Management Oxford:Elsevier.

Lessing, N. and Scheepers, C. 2004. Information is a management issue ( $9^{\text {th }}$ ed.). Johannesburg:CSIC Publishers.

Moscove, S.A., Simkin, M.G. and Bagranoff, N.A. 1990. Accounting information systems. 4th Edition. Singapore:Wiley.

Nieman, G. and Bennett, A. 2002. Business management. Pretoria:Van Schaik.

Nord, J.H. and Nord, G.D. 1995. Executive information systems: A Study and comparative analysis. Information \& Management, 29(2):95-106.

Olson, D.I. and Courtney, J.F. 1992. Decision support models and expert systems. New York:Macmillan. 


\section{E. Papageorgiou HEC de Bruyn}

Using executive information systems as a business management tool in listed Johannesburg Stock Exchange (JSE) companies: an exploratory study

Palvia, P. Kumar, A, Kumar, N. and Hendon, R. 1996. Information requirements of a global EIS: An exploratory macro assessment. Decision Support Systems, 16(2):169-179.

Parker, M.M. 1996. Strategic transformation and information technology. Upper Saddle River:PrenticeHall.

Rainer, R.K. and Watson, H.J. 1995. What does it take for successful executive information system? Decision Support Systems, 14(2):147-156.

Rockart, J.F. and Treacy, M.E. 1982. The CEO goes on-line. Harvard Business Review, Jan-Feb:82-88.

Saunders, G. 1988. The emergence of the information system executive. Johannesburg: University of the Witwatersrand (MBA).

Salmeron, J.I. 2002. EIS date: findings from an evolutionary study. The Journal of Systems and Software, 64(2):111-114.

Sawy, A.E. 1989. How to make DSS EIS ready: DSS-89 Transactions, Ninth International conference on Decision Support Systems, Edited by GR Widmeyer. Providence:College on Information Systems.

Stephenson, B.Y. 1986. Information: A strategic business weapon: DSS-86 Transactions, Sixth international conference on Decision Support Systems, Edited by $\mathrm{J}$ Fedorowicz. Washington:College on Information Systems.

Sterrenberg, G.K. 1990. The structure of executive information systems. Johannesburg: University of the Witwatersrand (MBA).

Sutherland, F. 1994. The development of effective information management through executive information systems. Johannesburg:University of the Witwatersrand (MBA).

Turban,E. 1993. Decision support and expert systems. ( $3^{\text {rd }}$ ed.). New York:Macmillan.

Turban, E., Mclean, E. and Wetherbe, J. 1996. Information technology for management. Toronto:Wiley.

Valusek, J.R. and Fryback, D.G. 1990. Information requirements determination: Obstacles within, among and between participants in Galliers R, Information Analysis. Sydney:Addison-Westley.

Venter, J.M.P. 2002. A survey of current online reporting practices in South Africa. Meditari Accountancy Research, 10:209-225.

Walstrom, K.A. and Wilson, R.I. 1997. Gaining user acceptance of an EIS. Information Systems Management, 14(1):54-59.

Watson, H.J., Watson, R.T., Singh, S. and Holmes, D. 1995. Development practices for executive information systems: Findings of a field study. Decision Support Systems, 14(2):171-184.

Xu, X.M. and Kaye, G.R. 2002. Knowledge workers for information support: Executives' perceptions and problems. Information Systems Management, 19(1):81-90.

Young, D. and Watson, H.J. 1995. Determinants of EIS acceptance. Information and Management, 29(3):153-164. 